\title{
Application of X-ray fluorescence method for elemental analysis of PM2.5 fraction
}

Lucyna Samek, Leszek Furman, Tomasz Kawik, Kinga Welnogorska

\begin{abstract}
The scientific interest in air pollution comes from its influence on human health, the condition of cultural heritage and climate. The PM2.5 fraction (particles of a diameter of $2.5 \mathrm{~mm}$ or below), indirectly, has a significant impact on health which is associated with respiratory tract and blood vessel related diseases. However, not only the size, but also the content of the particles has a significant meaning. To determine the particulate matter contents, elemental analysis can be performed using numerous techniques, the most important of which is X-ray fluorescence. In this study, samples of PM2.5 fraction collected in Krakow, Poland were analyzed. The X-ray fluorescence method was used to perform elemental analysis. The gravimetric method was applied to determine the concentration of the PM2.5 fraction. Low detection limits of individual elements and precision of the X-ray fluorescence method were determined. The concentrations of the following elements: $\mathrm{Cl}, \mathrm{K}, \mathrm{Ca}$, $\mathrm{Cr}, \mathrm{Mn}, \mathrm{Fe}, \mathrm{Cu}, \mathrm{Zn}, \mathrm{Br}, \mathrm{Rb}, \mathrm{Sr}$ and $\mathrm{Pb}$ in the PM2.5 fraction samples collected in Krakow were evaluated. The homogeneity of the samples was also estimated. The concentrations of PM2.5 fraction collected in the summer of 2013 were in the range of $6-23 \mathrm{ng} / \mathrm{m}^{3}$. The concentrations of PM2.5 fraction collected in the winter of 2013 were in the range of $26-171 \mathrm{ng} / \mathrm{m}^{3}$. The precision of the method was found to be below $1 \%$ for elements with high concentration in the sample and 6-8 \% for trace elements.
\end{abstract}

Key words: air pollution • energy dispersive X-ray fluorescence (EDXRF) • elemental analysis • particulate matter

L. Samek ${ }^{凶}$, L. Furman, T. Kawik, K. Welnogorska Faculty of Physics and Applied Computer Science, AGH University of Science and Technology, 30 Mickiewicza Ave., 30-059 Krakow, Poland, Tel.: +48 12617 2975, Fax: +48 12634 0010, E-mail: Lucyna.Samek@fis.agh.edu.pl

Received: 17 September 2014

Accepted: 20 May 2015

\section{Introduction}

Air pollution, especially particulate matter (PM), can influence human health, the condition of cultural heritage and climate. Initial studies of air pollution involved the analysis of the PM10 fraction (particulate matter with particle diameter less or equal to $10 \mu \mathrm{m}$ ). The PM10 fraction was broadly characterized from the perspective of several physicochemical aspects [1-3]. Currently an increasing amount of research is being conducted focusing on the characterization of the PM2.5 fraction [4-6]. This is due to the fact that small particles can much more easily penetrate the human respiratory tract. These particles have been associated with both short-term and long-term adverse health effects, including chronic respiratory disease, heart disease, lung cancer and damage to other organs [7]. The effects on human health are related to both chemical and physical properties of particulate matter. The chemical content of particulate matter has a significant effect on its toxicity [8]. Characterization of the components of PM2.5, including inorganic ele- 
ments, is of great importance when proposing possible mechanisms of negative health effects and when performing source apportionment studies. Several physiochemical methods are used to determine elemental concentrations in the PM2.5 fraction. In order to perform atomic emission spectrometry with inductively coupled plasma (ICP-AES), optical emission spectrometry with inductively coupled plasma (ICP-OES) or atomic absorption spectrometry (AAS) analysis, it is required to follow appropriate preparation steps prior to analyzing collected samples. This requires dissolving the PM2.5 samples in an acid solution. Contrary to these techniques, using the XRF (X-ray fluorescence) method does not involve any preparation of the samples for analysis. As a result the samples are not destroyed and can be further used for other purposes. For this reason, XRF analysis is suitable and preferred for PM2.5 analysis.

In this work, samples of PM2.5 fraction were collected in Krakow, Poland and extensively analyzed. The X-ray fluorescence method was used in order to perform elemental analysis of the PM2.5 fraction. The gravimetric method was applied to determine the concentration of the PM2.5 fraction. Low detection limits of elements and precision of the X-ray fluorescence method were further determined. Additionally, the homogeneousness of the PM2.5 samples was assessed. Subsequently, the concentrations of elements in the PM2.5 fraction collected in Krakow were evaluated. The results obtained for two different seasons, summer and winter, were compared.

\section{Experimental}

\section{Sampling}

The site selected for the experiment was an area of an urban background in Krakow [9]. It was located in the district of Krowodrza in the western part of the city (Krakow; 500.'01"N; 1954'47"E). It was a build-up area in the vicinity of a park. PM concentrations at the site are considered representative of the concentrations in the residential area of the city. The main local source of pollution is municipal combustion, industry and traffic. Traffic density in the city is very high with frequent traffic jams. In the eastern part of the city, industry is a major contributor to air pollution. This includes the steel and ferrous, ceramics and building industries and heat and power plants. Industrial factories are located at a distance of about $10 \mathrm{~km}$ from sampling site. There is also a power plant in the southern area of the city. The Upper Silesian industry area is located approx. $80 \mathrm{~km}$ to the west from Krakow. Moreover, the zinc industry is situated about $50 \mathrm{~km}$ to the north of the city. PM2.5 fraction samples were collected in 24-hour periods from the 14th to the 25th of January 2013 and from the 12th June to the 4th of July 2013 with the use of a Low Volume LVS-3 Sampler with a flow rate of $2.3 \mathrm{~m}^{3} / \mathrm{h}$. Samples were collected on teflon PTFE $(46.2 \mathrm{~mm}$, $2 \mu \mathrm{m}$ for PM2.5) filters. A total of 30 samples were collected during the summer and winter of 2013.

\section{Chemical analysis}

Filters were weighed on a micro-balance (A and D INSTRUMENTS HM-202-EC, accuracy $0.01 \mathrm{mg}$ ) in a clean room (temperature: $20 \pm 1^{\circ} \mathrm{C}$, RH: $50 \pm 5 \%$ ) to evaluate the mass of the PM2.5 fraction following procedures outlined in literature $[10,11]$. Filter weight before and after sampling was recorded and the average of three separate weightings was reported. PM2.5 concentrations were calculated using the mass values of collected dust and volumes of air that passed through the sampler. The substrates were conditioned for $48 \mathrm{~h}$ in a weighing room before and after sampling. Concentrations of the following elements were determined: $\mathrm{Cl}, \mathrm{K}, \mathrm{Ca}$, $\mathrm{Cr}, \mathrm{Mn}, \mathrm{Fe}, \mathrm{Cu}, \mathrm{Zn}, \mathrm{Br}, \mathrm{Sr}, \mathrm{Rb}$ and $\mathrm{Pb}$. Samples of PM2.5 were analyzed with the use of a multifunctional energy dispersive X-ray fluorescence spectrometer as thin samples. The instrument is a microbeam X-ray fluorescence spectrometer with capillary X-ray optics, a broad X-ray beam from Mo secondary target for XRF analysis of bulk samples and a total reflection X-ray technique. The Mo tube is the source of the X-rays. The tube has a power of $2 \mathrm{~kW}$. The excited X-rays were detected by a $\mathrm{Si}(\mathrm{Li})$ detector with a resolution of $170 \mathrm{eV}$ at an energy of $5.9 \mathrm{keV}$. Data collection was completed using the Canberra system. The measurements were carried out under the following conditions: voltage of $55 \mathrm{kV}$, current of $30 \mathrm{~mA}$, measuring time of $10000 \mathrm{~s}$, under atmospheric air. In order to calculate the concentrations of different elements in the filters, the spectrometer was calibrated using thin-film standards (Micromatter, U.S.A.). Calibration was verified by the analysis of the NIST Standard Reference Material (SRM) 2783 (Table 1 - Air particulate matter on filter media). The XRF spectra were quantitatively analyzed with the use of the QXAS package [12].

\section{Results and discussion}

The calibration of the spectrometer was performed and yielded satisfactory results (Table 1). Measured values were equal to certified values within measured uncertainties for most of the elements with the exception of $\mathrm{Ca}$ and $\mathrm{Zn}$, for which the measured values were within extended uncertainties. Subse-

Table 1. Air particulate matter on filter media in NIST SRM2783

\begin{tabular}{lcc}
\hline \multicolumn{1}{c}{ Element } & $\begin{array}{c}\text { Measured values } \\
{[\mathrm{ng}]}\end{array}$ & $\begin{array}{c}\text { Certified values } \\
{[\mathrm{ng}]}\end{array}$ \\
\hline $\mathrm{K}$ & $6100 \pm 710$ & $5280 \pm 520$ \\
$\mathrm{Ca}$ & $18400 \pm 2000$ & $13200 \pm 1700$ \\
$\mathrm{Ti}$ & $1230 \pm 35$ & $1490 \pm 240$ \\
$\mathrm{Cr}$ & $169 \pm 70$ & $135 \pm 25$ \\
$\mathrm{Mn}$ & $294 \pm 35$ & $320 \pm 12$ \\
$\mathrm{Fe}$ & $28230 \pm 940$ & $26500 \pm 1600$ \\
$\mathrm{Ni}$ & $80 \pm 20$ & $68 \pm 12$ \\
$\mathrm{Cu}$ & $393 \pm 15$ & $404 \pm 42$ \\
$\mathrm{Zn}$ & $2052 \pm 110$ & $1790 \pm 130$ \\
$\mathrm{~Pb}$ & $364 \pm 5$ & $317 \pm 54$ \\
\hline
\end{tabular}


quently, the SRM standard was measured ten times and the precision of the method was determined. The results of the precision calculations are presented in Table 2. The table shows mean mass values from ten measurements, standard deviations in ng and relative standard deviations in percentages. The detection limits for SRM 2783 were also calculated and can be seen in the last column of Table 2. The obtained precision of the EDXRF method was about $1 \%$ for elements with high concentration in the sample and 6-8\% for trace elements. The highest precision value was obtained for $\mathrm{Cr}$; it was equal to $18 \%$. An improvement in the precision value for this element can be achieved by extending the measurement time. It is stated that the precision of an analytical method should be below 5\% for elements present in high concentrations and below $15 \%$ for trace elements. This allows the conclusion that the obtained precision results were accurate. The EDXRF method can thus be successfully used for elemental analysis of PM2.5 fraction.

The homogeneity of one representative PM2.5 sample was determined. Measurements were performed using eleven data points from the sample. The concentrations of elements were calculated for each individual point. The $\chi 2$ test was performed on the basis of elemental concentrations. A hypothesis stating that the sample has a uniform distribution was established. The $\chi 2$ test was carried out for every element using the following formula:

$$
\chi^{2}=\sum_{k=1}^{n} \frac{\left(\mathrm{Q}_{k}-E\right)}{\sigma_{k}^{2}}
$$

where: $\mathrm{Q}_{k}$ - measured value - concentration of measurement $k ; E$ - expected value - mean value of the element's concentration; $\sigma_{k}$ - uncertainty of measurement $k$.

The degrees of freedom value was determined based on the subsequent equation:

$$
d=n-c-1
$$

where: $d$-degrees of freedom; $n$ - number of measurements, $c$-number of parameters of theoretical model evaluated on the basis of measured data .

The parameter $p$ was read from a statistical table after the computations were completed. The results are shown in Table 3 . The $\chi 2$ test confirmed that the sample was homogenous on a confidence level of above $90 \%$ for most elements. In the case of Fe and $\mathrm{Pb}$, the sample was homogenous on a confidence level of above $80 \%$. It was impossible to conclude whether $\mathrm{Cu}$ was homogenously distributed within the sample based on the obtained results. However, it is worth mentioning that the concentration of $\mathrm{Cu}$ was equal to the detection limit.

Concentrations of the PM2.5 fraction during two different seasons (winter and summer 2013) are shown in Fig. 1. The observed concentration values of PM2.5 were determined to be higher in winter than in summer. The maximum value was reported on January 24th, $2013\left(171 \mu \mathrm{g} / \mathrm{m}^{3}\right)$ and the minimum value was noted on June $25 \mathrm{th}, 2013$ $\left(6 \mu \mathrm{g} / \mathrm{m}^{3}\right)$. Mean values were equal to $74 \mu \mathrm{g} / \mathrm{m}^{3}$ and

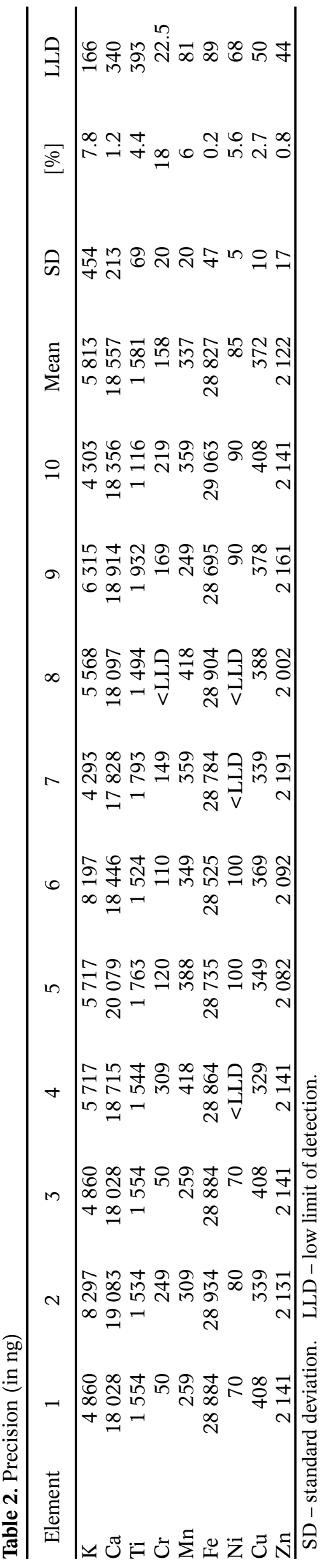


Table 3. Test $\chi 2$

\begin{tabular}{|c|c|c|c|c|}
\hline Element & $E\left[\mathrm{ng} / \mathrm{m}^{3}\right]$ & $\chi^{2}$ & $d$ & $p$ \\
\hline$\overline{\mathrm{K}}$ & 519 & 0.697 & 9 & $>0.999$ \\
\hline $\mathrm{Ca}$ & 227 & 0.569 & 9 & $>0.999$ \\
\hline $\mathrm{Fe}$ & 104 & 4.207 & 9 & 0.897 \\
\hline $\mathrm{Cu}$ & 8.2 & 9.286 & 9 & 0.411 \\
\hline $\mathrm{Zn}$ & 42.6 & 3.576 & 9 & 0.937 \\
\hline $\mathrm{Br}$ & 6.7 & 3.636 & 9 & 0.934 \\
\hline $\mathrm{Pb}$ & 15.9 & 4.616 & 9 & 0.820 \\
\hline
\end{tabular}
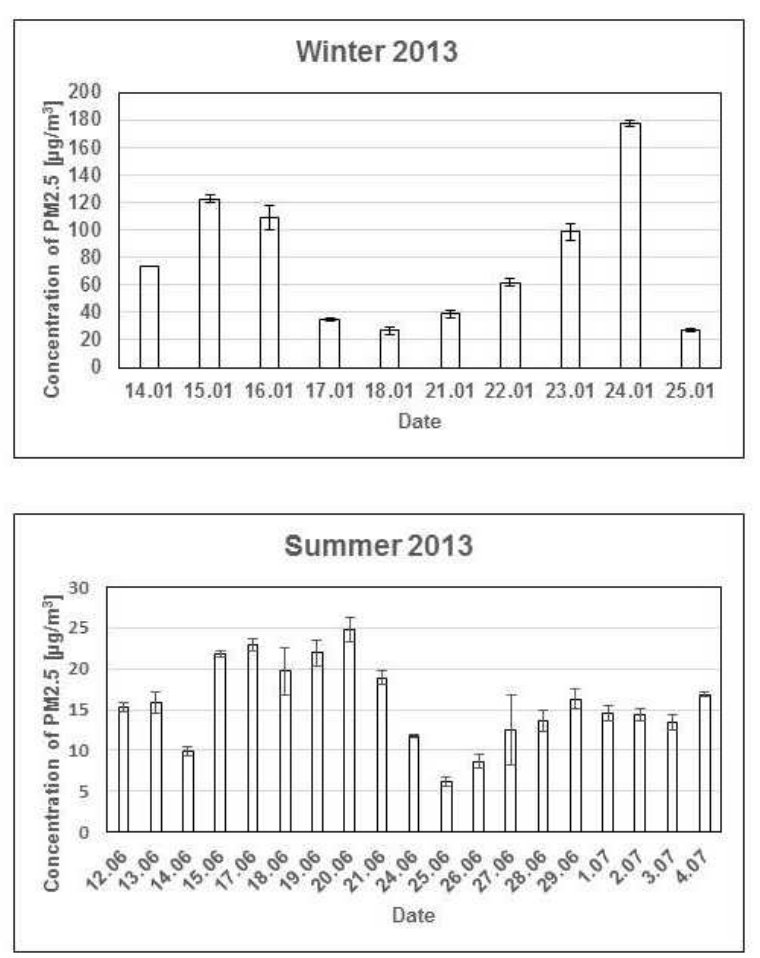

Fig. 1. Concentrations of PM2.5 fraction for winter and summer 2013.

$16 \mu \mathrm{g} / \mathrm{m}^{3}$ for winter and summer, respectively. Values obtained for other Polish cities - annual in Katowice, Zabrze and winter-spring in Wroclaw, were lower than those found in winter in Krakow. The numbers reported for the above mentioned Polish cities were higher than those observed in summer in Krakow [13]. Putaud et al. presented data on PM2.5 annual average concentrations for several cities in Europe and found them to be in the range of $3-35 \mu \mathrm{g} / \mathrm{m}^{3}$. It can be seen that the results obtained during summer in Krakow were in fact in the range stated by Putaud et al. and those attained during winter exceeded the average annual concentrations [14]. These high values of PM2.5 concentrations may be associated with the fact that combustion due to heating is more common in Krakow than in other European cities during winter months.

The results of elemental analysis of PM2.5 are presented in Table 4 . The table contains the minimum, maximum and mean values for both, winter and summer times. Additionally, Table 4 shows the low limits of detection (LLD) for the analyzed elements. Concentrations of the following elements were determined: $\mathrm{Cl}, \mathrm{K}, \mathrm{Ca}, \mathrm{Mn}, \mathrm{Fe}, \mathrm{Cu}, \mathrm{Zn}, \mathrm{Br}$, $\mathrm{Sr}, \mathrm{Rb}$ and $\mathrm{Pb}$. Chlorine was present only in the samples collected during winter with a maximum value equal to $10.314 \mathrm{ng} / \mathrm{m}^{3}$ and a mean value of $2.116 \mathrm{ng} / \mathrm{m}^{3}$. The mean concentration of potassium in winter significantly exceeded the one obtained in summer. The mean concentration of calcium was three times higher in winter than in summer. The mean concentrations of $\mathrm{Zn}, \mathrm{Br}$ and $\mathrm{Pb}$ were twice as high in winter than in summer. However, opposite results were determined for $\mathrm{Fe}$ and $\mathrm{Cu}$. In winter, the mean concentrations of $\mathrm{Fe}$ and $\mathrm{Cu}$ were two times lower than in summer. Mean concentrations of $\mathrm{Zn}, \mathrm{Br}$ and $\mathrm{Pb}$ in winter in Krakow were lower than annual in Katowice and winter-spring in Wroclaw. But they were higher than annual in Zabrze. However, mean concentrations of $\mathrm{Zn}, \mathrm{Br}$ and $\mathrm{Pb}$ in summer in Krakow were lower than in the above Table 4. PM2.5 concentrations (in $\mu \mathrm{g} / \mathrm{m}^{3}$ ) and elemental concentrations of PM2.5 (in $\mathrm{ng} / \mathrm{m}^{3}$ ) in Krakow

\begin{tabular}{|c|c|c|c|c|c|c|c|}
\hline \multirow{2}{*}{ Element } & \multicolumn{3}{|c|}{ Winter 2013} & \multicolumn{3}{|c|}{ Summer 2013} & \multirow{3}{*}{ LLD } \\
\hline & Min & Max & Mean \pm SD & Min & Max & Mean \pm SD & \\
\hline PM2.5 & 26 & 171 & $74 \pm 38$ & 6 & 25 & $16 \pm 4$ & \\
\hline$\overline{\mathrm{Cl}}$ & $<$ LLD & 10314 & $2116 \pm 3510$ & $<$ LLD & $<$ LLD & $<$ LLD & 250 \\
\hline $\mathrm{K}$ & 91 & 4867 & $1666 \pm 897$ & $<\mathrm{LLD}$ & 311 & $123 \pm 68$ & 30 \\
\hline $\mathrm{Ca}$ & $<\mathrm{LLD}$ & 1227 & $440 \pm 326$ & $<\mathrm{LLD}$ & 288 & $146 \pm 73$ & 20 \\
\hline $\mathrm{Mn}$ & $<\mathrm{LLD}$ & 75 & $7.5 \pm 14$ & $<$ LLD & 23 & $6.7 \pm 5$ & 3.5 \\
\hline $\mathrm{Fe}$ & $<\mathrm{LLD}$ & 356 & $130 \pm 101$ & 51 & 778 & $234 \pm 133$ & 2.5 \\
\hline $\mathrm{Cu}$ & $<\mathrm{LLD}$ & 15 & $2 \pm 8$ & 2 & 27 & $6 \pm 3$ & 1.8 \\
\hline $\mathrm{Zn}$ & 45 & 302 & $151 \pm 77$ & 16 & 198 & $67 \pm 35$ & 1.5 \\
\hline $\mathrm{Br}$ & $<\mathrm{LLD}$ & 28 & $8 \pm 11$ & 1 & 7 & $4 \pm 1$ & 1.0 \\
\hline $\mathrm{Rb}$ & <LLD & 45 & $20 \pm 9$ & $<\mathrm{LLD}$ & 1.3 & 0.6 & 1.0 \\
\hline $\mathrm{Sr}$ & $<\mathrm{LLD}$ & 1.1 & $<$ LLD & $<\mathrm{LLD}$ & 0.9 & 0.3 & 1.0 \\
\hline $\mathrm{Pb}$ & $<\mathrm{LLD}$ & 86 & $30 \pm 31$ & 3.7 & 29 & $13 \pm 5$ & 2.0 \\
\hline
\end{tabular}

Note: SD represents the variability of elemental concentrations in all collected samples.

LLD - low limit of detection. 

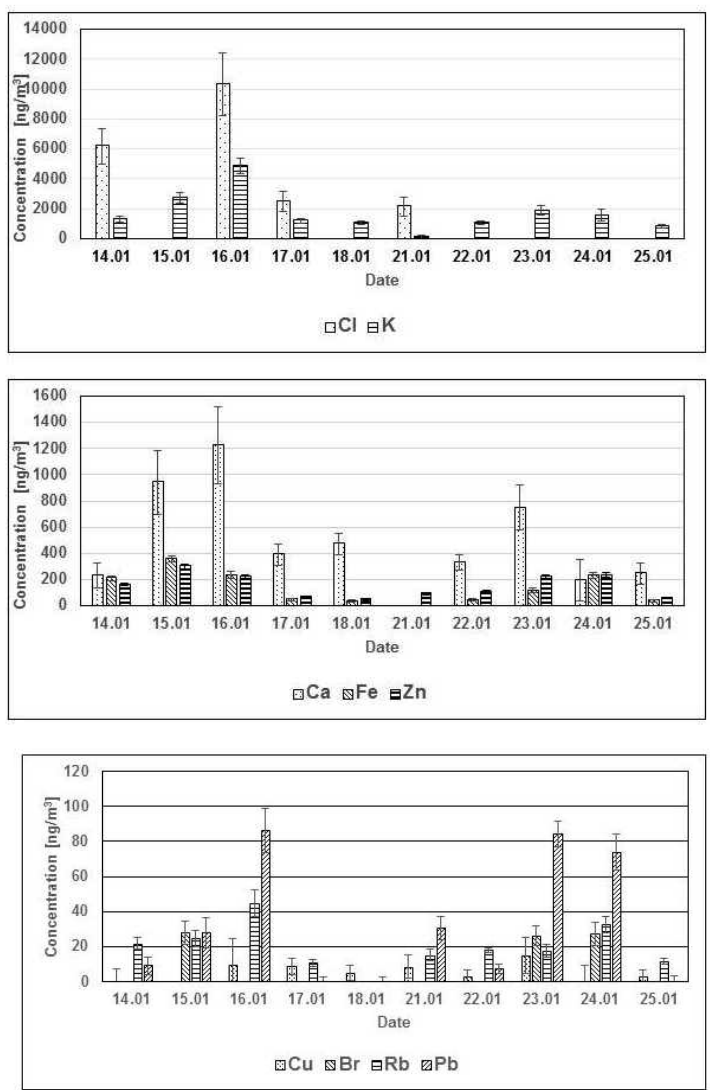

Fig. 2. Elemental concentrations in PM2.5 fraction for winter 2013.

mentioned cities [13]. Mean concentration of Fe in summer in Krakow was higher than annual in Katowice, Zabrze and winter-spring in Wroclaw. Mean concentration of $\mathrm{Fe}$ in winter in Krakow was lower than annual in Katowice and Zabrze and higher in winter-spring in Wroclaw [13]. The daily elemental concentrations in winter and summer are shown in Figs. 2 and 3, respectively. The highest concentrations of the following elements: $\mathrm{Cl}, \mathrm{K}, \mathrm{Ca}, \mathrm{Fe}, \mathrm{Zn}$, $\mathrm{Rb}$ and $\mathrm{Pb}$, were observed on January 16th. The highest concentrations of $\mathrm{Cu}$ and $\mathrm{Pb}$ were noted on June 13th. Whereas, the highest concentrations of $\mathrm{K}, \mathrm{Ca}, \mathrm{Fe}$ and $\mathrm{Zn}$ were detected on June 20th. The results obtained during this study will serve as a reference for future work focusing on the investigation of air pollution. Few studies, which include data relevant to the same time of the year, have been previously completed. Therefore, it is currently difficult to perform comparisons which would allow for
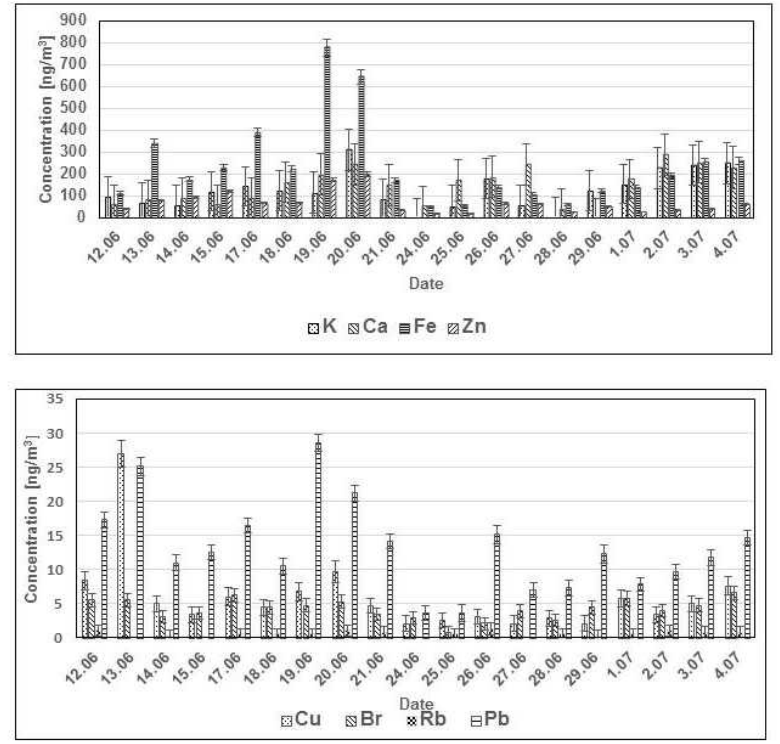

Fig. 3. Elemental concentrations in PM2.5 fraction for summer 2013.

a meaningful analysis of air pollution. This work and future studies may lead to a better understanding of the constituents of air pollution and their dependence on the time of year which will allow for an essential determination of the sources of air pollution. The correlations between concentrations of elements were calculated for winter and summer and are shown in Tables 5 and 6 , respectively. In winter a high correlation was observed between $\mathrm{K}, \mathrm{Ca}, \mathrm{Fe}, \mathrm{Rb}$ and $\mathrm{Cl}, \mathrm{Zn}$, $\mathrm{Pb}$. A high correlation coefficient was also calculated for $\mathrm{Zn}$ and $\mathrm{Fe}, \mathrm{Br}, \mathrm{Rb}$ and $\mathrm{Pb}$. The element which did not correlate with others was $\mathrm{Cu}$. In the summer, $\mathrm{K}$ was correlated with $\mathrm{Ca}$ and $\mathrm{Rb}$. Fe was correlated with $\mathrm{Mn}, \mathrm{Zn}$ and $\mathrm{Pb}$. Additionally, $\mathrm{Cu}$ was correlated with $\mathrm{Pb}$. The sources of fine fraction could be the mixture of combustion processes of coal, waste, biomass and emission from vehicles and industry. The ratio $\mathrm{Pb} / \mathrm{Br}$ equal to 3.75 in winter and 3.25 in summer suggested that one of the sources of PM2.5 can be combustion of fossil fuel. The ratio $\mathrm{Zn} / \mathrm{Pb}$ equal to 5.03 in winter and 5.15 in summer suggested that the source of PM2.5 can be combustion in homes or/and fossil fuel [15].

\section{Conclusions}

EDXRF has been described as significant, very useful and convenient when determining concentra-

Table 5. Correlation between concentrations of elements - winter 2013

\begin{tabular}{lccccrrrrr}
\hline \multicolumn{1}{c}{ Element } & $\mathrm{Cl}$ & $\mathrm{K}$ & $\mathrm{Ca}$ & $\mathrm{Fe}$ & \multicolumn{1}{c}{$\mathrm{Cu}$} & $\mathrm{Zn}$ & $\mathrm{Br}$ & $\mathrm{Rb}$ & $\mathrm{Pb}$ \\
\hline $\mathrm{Cl}$ & 1.00 & 0.63 & 0.35 & 0.28 & 0.25 & 0.15 & -0.42 & 0.61 & 0.30 \\
$\mathrm{~K}$ & 0.63 & 1.00 & $\mathbf{0 . 8 9}$ & $\mathbf{0 . 6 8}$ & -0.16 & 0.64 & 0.21 & $\mathbf{0 . 7 7}$ & 0.60 \\
$\mathrm{Ca}$ & 0.35 & $\mathbf{0 . 8 9}$ & 1.00 & 0.59 & -0.23 & 0.56 & 0.29 & 0.47 & 0.40 \\
$\mathrm{Fe}$ & 0.28 & $\mathbf{0 . 6 8}$ & 0.59 & 1.00 & -0.68 & $\mathbf{0 . 9 0}$ & 0.61 & $\mathbf{0 . 7 0}$ & 0.47 \\
$\mathrm{Cu}$ & 0.25 & -0.16 & -0.23 & -0.68 & 1.00 & -0.53 & -0.47 & -0.15 & 0.14 \\
$\mathrm{Zn}$ & 0.15 & 0.64 & 0.56 & $\mathbf{0 . 9 0}$ & -0.53 & 1.00 & $\mathbf{0 . 7 9}$ & $\mathbf{0 . 7 3}$ & $\mathbf{0 . 7 3}$ \\
$\mathrm{Br}$ & -0.42 & 0.21 & 0.29 & 0.61 & -0.47 & $\mathbf{0 . 7 9}$ & 1.00 & 0.30 & 0.57 \\
$\mathrm{Rb}$ & 0.61 & $\mathbf{0 . 7 7}$ & 0.47 & $\mathbf{0 . 7 0}$ & -0.15 & $\mathbf{0 . 7 3}$ & 0.30 & 1.00 & $\mathbf{0 . 7 7}$ \\
$\mathrm{Pb}$ & 0.30 & 0.60 & 0.40 & 0.47 & 0.14 & $\mathbf{0 . 7 3}$ & 0.57 & $\mathbf{0 . 7 7}$ & 1.00 \\
\hline
\end{tabular}


Table 6. Correlation between concentrations of elements - summer 2013

\begin{tabular}{lccccccccc}
\hline \multicolumn{1}{c}{ Element } & $\mathrm{K}$ & $\mathrm{Ca}$ & $\mathrm{Mn}$ & $\mathrm{Fe}$ & $\mathrm{Cu}$ & $\mathrm{Zn}$ & $\mathrm{Br}$ & $\mathrm{Rb}$ & $\mathrm{Pb}$ \\
\hline $\mathrm{K}$ & 1.00 & 0.64 & 0.38 & 0.47 & 0.09 & 0.40 & 0.49 & 0.64 & 0.37 \\
$\mathrm{Ca}$ & 0.64 & 1.00 & 0.27 & 0.32 & -0.07 & 0.17 & 0.10 & 0.48 & 0.06 \\
$\mathrm{Mn}$ & 0.38 & 0.27 & 1.00 & $\mathbf{0 . 8 2}$ & 0.30 & $\mathbf{0 . 7 7}$ & 0.37 & 0.04 & $\mathbf{0 . 6 9}$ \\
$\mathrm{Fe}$ & 0.47 & 0.32 & $\mathbf{0 . 8 2}$ & 1.00 & 0.38 & $\mathbf{0 . 8 8}$ & 0.46 & 0.15 & $\mathbf{0 . 8 2}$ \\
$\mathrm{Cu}$ & 0.09 & -0.07 & 0.30 & 0.38 & 1.00 & 0.26 & 0.46 & -0.12 & 0.65 \\
$\mathrm{Zn}$ & 0.40 & 0.17 & $\mathbf{0 . 7 7}$ & $\mathbf{0 . 8 8}$ & 0.26 & 1.00 & 0.30 & 0.03 & $\mathbf{0 . 7 1}$ \\
$\mathrm{Br}$ & 0.49 & 0.10 & 0.37 & 0.46 & 0.46 & 0.30 & 1.00 & 0.06 & 0.52 \\
$\mathrm{Rb}$ & 0.64 & 0.48 & 0.04 & 0.15 & -0.12 & 0.03 & 0.06 & 1.00 & 0.20 \\
$\mathrm{~Pb}$ & 0.37 & 0.06 & $\mathbf{0 . 6 9}$ & $\mathbf{0 . 8 2}$ & 0.65 & $\mathbf{0 . 7 1}$ & 0.52 & 0.20 & 1.00 \\
\hline
\end{tabular}

tions of elements in the PM2.5 fraction. The crucial characteristic of this method is that the analyzed samples are not destroyed and can be further used for other purposes. The precision values of EDXRF in this study were low, up to $1 \%$ for elements which appeared in high concentrations in the sample and $6-8 \%$ for trace elements. It was determined that for almost all of the elements the analyzed samples were homogeneous on the level of confidence exceeding $90 \%$. The seasonal variation of elemental concentrations showed that higher concentrations of elements such as $\mathrm{Cl}, \mathrm{K}, \mathrm{Ca}, \mathrm{Br}$ and $\mathrm{Pb}$ were observed in winter season than in summer. However, concentrations of $\mathrm{Fe}$ and $\mathrm{Cu}$ were higher in summer than in winter. The obtained elemental concentrations were compared to the data available in literature and it was determined that the values were similar to those reported for other Polish and European cities.

Acknowledgments. The International Atomic Energy Agency, project no. RER/1/008, together with the Polish Ministry of Science and Higher Education and its grants for Scientific Research partially financed this work.

\section{References}

1. Bari, M. A., Baumbach, G., Sarachage-Ruiz, L., \& Kleanthes, S. (2009). Identification of PM10 sources in Mediterranean Island. Water Air Soil Poll. Focus, 9, 39-53. DOI: 10.1007/s11267-008-9194-6.

2. Lazaridis, M., Dzumbova, L., Kopanakis, I., Ondracek, J., Glytsos, T., Aleksandropoulou, V., Voulgarakis, A., Katsivela, E., Mihelopoulos, N., \& Eleftheriadis, K. (2008). PM10 and PM2.5 levels in the Eastern Mediterranean (Akrotiri Research Station, Crete, Greece). Water Air Soil Poll., 199, 85-101. DOI: 10.1007/s11270-007-9558-y.

3. Samek, L. (2012). Source apportionment of the PM10 fraction of particulate matter collected in Krakow, Poland. Nukleonika, 57, 601-606.

4. Remoundaki, E., Papayannts, A., Kassomenos, P., Mantas, E., Kokkalis, P., \& Tsezos, M. (2013). Influence of Saharan Dust Transport events on PM2.5 concentrations and composition over Athens. Water Air Soil Poll., 224, 1373-1776. DOI: 10.1007/s11270-012-1373-4.

5. Vallius, M., Janssen, N. A., Heinrich, J., Hoek, G., Runskane, J., Cyrys, J., \& Van Grieken, R. (2005). Sources and elemental composition of ambient PM2.5 in three European cities. Sci. Total Environ., 337, 147-162. DOI: 10.1016/j.scitotenv.2004.06.018.
6. Samek, L., Gdowik, A., Ogarek, J., \& Furman, L. (2016). Elemental composition and rough source apportionment of fine particulate matter in Krakow, Poland. Env. Prot. Eng. (in press).

7. Niu, J., Rasmussen, P. E., Wheeler, A., Williams, R., \& Chenier, M. (2010). Evaluation of airborne particulate matter and metals data in personal, indoor and outdoor environments using ED-XRF and ICP-MS and co-located duplicate samples. Atmos. Environ., 44, 235-245. DOI: 10.1016/j.atmosenv.2009.10.009.

8. Karanasiou, A. A., Sitaras, L. E., Siskos, P. A., \& Eleftheriadis, K. (2007). Size distribution and sources of trace metals and n-alkanes in the Athens urban aerosol during summer. Atmos. Environ., 41, 2368-2381. DOI: 10.1016/j.atmosenv.2006.11.006.

9. Directive 2008/50/EC of the European Parliament and of the Council of 21 May 2008.

10. PN-EN 12341:2006a: Air quality - Determination of the PM10 fraction of suspended particulate matter-reference method and field test procedure to demonstrate reference equivalence of measurement methods.

11. PN-EN 14907:2006b: Ambient air quality - Standard gravimetric measurement method for the determination of the PM2.5 mass fraction of suspended particular matter.

12. Vekemans, B., Janssens, K., Vincze, L., Adams, F., \& Van Espen, P. (1994). Analysis of X-ray spectra by iterative least squares (AXIL): new developments. $X$-Ray Spectrom., 23, 278-285.

13. Rogula-Kozlowska, W., Klejnowski, K., Zwozdziak, A., Sowka, I., \& Trzepla-Nabaglo, K. (2011). Elemental composition and sources of PM2.5 in three Silesian cities, Wroclaw, Zabrze and Katowice, Poland. Nauka, Przyroda, Technologie, 5(4), 1-8.

14. Putaud, J. P., Van Dingenen, R., Alastuey, A., Bauer, H., Birmili, W., Cyrys, J., Flentje, H., Fuzzi, S., Gehring, R., Hansson, H. C., Harrison, R. M., Hermann, H., Hitzenberger, R., Huglin, C., Jones, A. M., Kasper-Giebl, A., Kiss, G., Kousa, A., Kuhlbusch, T. A. J., Loschau, G., Maenhaut, W., Molnar, A., Moreno, T., Pekkanen, J., Perrino, C., Pitz, M., Puxbaum, H., Querol, X., Rodriguez, S., Salma, L., Schwarz, J., Smolik, J., Schneider, J., Spindler, G., ten Brink, H., Tursic, J., Viana, M., Wiedensohler, A., \& Raes, F. (2010). A European aerosol phenomenology-3: Physical and chemical characteristics of particulate matter from 60 rural, urban, and kerbside sites across Europe. Atmos. Environ., 44, 1308-1320. DOI: 10.1016/j. atmosenv.2009.12.011

15. Watson, G. J., Chow, C. J., \& Houck, J. E. (2001). PM2.5 chemical source profiles for vehicle exhaust, vegetative burning, geological material and coal burning in Northwestern Colorado during 1995. Chemosphere, 43, 1141-1151. 